Tjalling C. Koopmans Research Institute Thlligh Aoopman

Discussion Paper Series nr: 11-20

\title{
The Impact of International Portfolio Composition on Consumption Risk Sharing
}

Nils Holinski

Clemens Kool

Joan Muysken 


\title{
Tjalling C. Koopmans Research Institute Utrecht School of Economics \\ Utrecht University
}

Kriekenpitplein 21-22

3584 TC Utrecht

The Netherlands

telephone $\quad+31302539800$

fax +31302537373

website www.koopmansinstitute.uu.nl

The Tjalling C. Koopmans Institute is the research institute and research school of Utrecht School of Economics.

It was founded in 2003, and named after Professor Tjalling C. Koopmans, Dutch-born Nobel Prize laureate in economics of 1975.

In the discussion papers series the Koopmans Institute publishes results of ongoing research for early dissemination of research results, and to enhance discussion with colleagues.

Please send any comments and suggestions on the Koopmans institute, or this series to J.M.vanDort@uu.nl

ontwerp voorblad: WRIK Utrecht

\author{
How to reach the authors \\ Please direct all correspondence to the last author. \\ Nils Holinski \\ Joan Muysken \\ Department of Economics \\ Maastricht University \\ PO BOX 616 \\ 6200 MD Maastricht \\ The Netherlands \\ Clemens Kool \\ Utrecht University \\ Utrecht School of Economics \\ Kriekenpitplein 21-22 \\ 3584 TC Utrecht \\ The Netherlands. \\ E-mail: c.j.m.kool@uu.nl
}


Utrecht School of Economics

Tjalling C. Koopmans Research Institute

Discussion Paper Series 11-20

\title{
The Impact of International Portfolio Composition on Consumption Risk Sharing
}

\author{
Nils Holinskia \\ Clemens Kool ${ }^{\mathrm{b}}$ \\ Joan Muyskena
}

${ }^{\mathrm{a} D e p a r t m e n t}$ of Economics
Maastricht University

bUtrecht School of Economics Utrecht University

November 2011

\begin{abstract}
Recent empirical work has shown that ongoing international financial integration facilitates cross-country consumption risk-sharing. These studies typically find that countries with high equity home bias exhibit relatively low international consumption risk sharing. We extend this line of research and demonstrate that it is not only a country's equity home bias that prevents consumption risk sharing. In addition, the composition of a country's foreign asset portfolio plays an important role. Using panel-data regression for a group of OECD countries over the period 1980-2007, we show that foreign investment bias has additional explanatory power for consumption risk sharing.
\end{abstract}

Keywords: international financial integration, foreign investment bias, geography of international investment, equity home bias, international portfolio diversification

JEL classification: F36, F41, G15 


\section{Introduction}

In recent years, international financial integration has broadened investment opportunity sets fundamentally. Investors increasingly have easy access to international capital markets that allow improved diversification and risk sharing. Lane and Milesi-Ferretti $(2001,2007,2008)$ show that gross foreign asset and liability positions as a fraction of GDP for a group of OECD countries have grown almost fivefold over the past two decades. Also they demonstrate that the composition of international balance sheets in terms of geographical allocation and currency denomination is highly heterogeneous.

Theoretical models of international financial markets (Obstfeld and Rogoff, 1996; LeRoy and Werner, 2001) demonstrate that perfect integration allows a decoupling of domestic consumption from idiosyncratic shocks to domestic output. In these models, countries can buy insurance against all future states of the world - that is all paths of future domestic output - and thereby shield their income and consumption from domestic output fluctuations. To test the above hypothesis, empirical analysis typically takes the regression proposed by Mace (1991), Cochrane (1991) and Lewis (1996) as a starting point. It specifies idiosyncratic consumption growth as the dependent variable and idiosyncratic output growth as the independent variable. Under perfect risk sharing, the regression coefficient converges to zero while under autarky the coefficient is equal to one. Early empirical research along these lines strongly rejects international financial integration and full consumption risk sharing.

More recent work assumes that the regression coefficient is a function of other economic or institutional variables which may be time-variant. Then, non-linear specifications result. Work along these lines by Fratzscher and Imbs (2009), Kose et al. (2009), Sørensen et al. (2007), and Bracke and Schmitz (2011) stresses the role of foreign investment for international consumption risk-sharing. Generally, the evidence shows that consumption 
risk sharing increases with higher financial openness and development and lower financial home bias.

In the current paper, we contribute to the literature above by accounting for the role of composition and geographical diversification in foreign equity portfolios. First, we argue that it is not the size of foreign portfolio investment as a fraction of domestic wealth alone that provides risk sharing. In addition, the composition of the foreign asset portfolio should matter as well. The closer the foreign portfolio weights - conditional on the market value of that portfolio - approximate the world portfolio, the better a country's risk sharing should be. Following Bekaert and Wang (2009) henceforth BW09 -, we use the term foreign investment bias to label deviations of actual from optimal portfolio weights. Note that equity home bias and foreign investment bias are expected to have complementary roles: high equity home bias in combination with an absence of foreign investment bias will not yield significant consumption risk sharing in general. On the other hand, low equity home bias together with extremely high foreign investment bias may not do the job either. In our paper, we use a foreign investment bias measure proposed by BW09 and Holinski (2010).

Second, we note that the overall degree of foreign investment bias may not be sufficient to measure the risk sharing potential of the foreign asset portfolio. That is, it matters in which countries there is overinvestment and in which underinvestment because countries differ in the degree of diversification benefits offered to the home economy. Underinvestment in countries with low diversification potential and simultaneous overinvestment in countries with high diversification potential is expected to yield higher benefits than the other way around. For this reason, we develop two measures of diversification potential. The first measure relies on the distance between countries as a proxy of information and familiarity problems. This variable is often used in gravity models of international trade (Melitz, 2007 and Fazio et al., 2008) as well as in the home bias literature (e.g. Chan, 
Covrig and Ng, 2005 and Ahearne, Griever and Warnock, 2004). ${ }^{1}$ The second is the bilateral GDP correlation, which is a direct measure of the degree of idiosyncratic shocks - and, thus, the degree of diversification potential between two countries. ${ }^{2}$ We use the two measures to develop adjusted weighted - versions of our simple overall foreign investment bias variable.

Our regression analysis covers a group of 21 OECD countries during the financial globalization period 1980-2007. Taking the work by Sørensen et al. (2007) as a benchmark and starting point, we use a panel regression framework to regress idiosyncratic consumption growth on idiosyncratic output growth where we specify the regression coefficient to be a function of a country's overall portfolio equity wealth, a country's equity home bias and a country's foreign investment bias. The results convincingly show that foreign investment bias plays a significant role in consumption risk sharing, complementing the effects of equity home bias and portfolio wealth.

The rest of the paper is organized as follows. Section 2 provides a brief literature review, while section 3 elaborates on the data and the development of home bias and foreign investment bias variables. In Section 4, we carry out the empirical analysis and present our results. Section 5 concludes.

\section{Literature review}

Our paper links two different strands of literature. On the one hand it draws on the traditional consumption risk sharing literature and its relation to financial openness and cross-border investment, on the other hand it uses insights from recent literature on the geography of international investment.

\footnotetext{
${ }^{1}$ See also Aviat and Coeurdacier (2007) and Portes and Rey (2005).

2 Alternatively, BW09 use the bilateral correlation between the stock market returns and the difference in industrial structure for each pair of countries as a measure of diversification potential.
} 
Empirical studies on international consumption risk sharing typically take two approaches to testing the hypothesis that consumption growth rates are highly correlated across countries. Early research focuses on the analysis of correlation patterns and compares cross-country output correlations with consumption correlations. Generally, one observes that output correlations are higher than consumption correlations, rejecting the null hypothesis of consumption risk sharing. This anomalous finding is known as the consumption correlation puzzle or quantity anomaly (notably Backus et al., 1992, Obstfeld, 1994, 1995, and Lewis, 1999). ${ }^{3}$

More recently, studies of international consumption risk-sharing interpret the hypothesis of perfect risk-sharing differently and seek to assess if consumption growth rates respond uniformly to aggregate, but not to country-specific output growth (Mace, 1991, Cochrane, 1991, Lewis (1996), Asdrubali et al., 1996, Sørensen and Yosha, 1998, Melitz and Zumer, 1999, Becker and Hoffmann, 2006). This strand of empirical research regresses idiosyncratic consumption growth on idiosyncratic output growth, where under the null hypothesis the $\beta$-coefficient is statistically indiscernible from zero. In case $\beta$ is above zero, it can be interpreted as the percentage deviation from the perfect risk-sharing case. Overall, the evidence rejects complete international risk sharing. However, for more recent periods that coincide with increased global financial integration more favorable results for risk sharing are found, particularly for developed countries.

In recent years, the basic regression specification has been extended to investigate the various channels through which consumption risk is shared and to link the degree of risk sharing directly to the level of financial development and the depth of financial markets, the level of financial openness and integration and the degree of home bias. The preferred

\footnotetext{
3 To reconcile empirical findings with theory, the benchmark model of perfect risk-sharing has been amended in several respects: in several respects: (1) tradable versus non-tradable goods (Lewis, 1996, 1999, Stockmann and Tesar, 1995, (2) market incompleteness (Kollmann, 1995, Shiller, 1993, Lewis, 1996), (3) transaction costs (Obstfeld, 2001). For an excellent survey see Kose et al. (2007).
} 
approach in this literature is to make the $\beta$-coefficient in the basic consumption risk sharing equation an explicit function of exogenous variables measuring financial integration.

Sørensen et al. (2007) document a marked increase in international income and consumption risk-sharing associated with high levels of foreign portfolio equity and foreign direct investment for the group of OECD countries. Fratzscher and Imbs (2009) extend the line of research to a bilateral context and confirm that intensity and composition (in terms of asset classes) of foreign assets are decisive determinants for the degree of risk-sharing between two countries. In particular, they find that financial assets with low transaction costs - bonds and equities - significantly provide international risk sharing. Note that Fratzscher and Imbs do pay attention to portfolio composition. However, they only distinguish different asset classes and pay no attention to geographical composition, whereas we focus on location choices for equities only. Kose et al. (2007) also use a number of measures for financial openness to show that industrial countries are the main beneficiaries of international risk sharing while the effect on developing countries so far is marginal. They point to threshold effects, structural and institutional problems and strong procyclicality in international capital flows to developing countries as underlying reasons for the lack of consumption risk sharing through financial integration. Bracke and Schmitz (2009) refine the analysis and show that the risk sharing properties of a foreign asset portfolio predominantly derive from countercyclical capital gains rather investment income. The potential for risk-sharing is found to be increasing since the mid-1990s for industrial countries, while absent in emerging market economies.

Becker and Hoffmann (2006) distinguish between permanent and transitory shocks. Using a VAR analysis, they find that cross-country risk sharing of transitory shocks between countries is of comparable magnitude as between US states, while smoothing permanent shocks through holdings of state 
contingent financial assets appears to be much more successful between US states than between countries. In related work, Artis and Hoffmann (2008) point out that consumption risk-sharing is a function of the structure of business cycles and that regression results are blurred by concurrent changes in them across countries. They account for transitory and persistent shocks to output and find that OECD countries are better able to insure against the former than the latter. For an overview of short run versus long run risk sharing, we refer to Baxter (2011).

The other strand of literature relevant to our paper is that on the geographical - determinants of foreign portfolio investment and their impact on international consumption-risk sharing. Drawing on the gravity model literature for international trade in goods, Lane and Milesi- Ferretti (2008) test an array of bilateral, host and source country characteristics to explain the structure of external equity portfolios for the year 2001. They show that underlying trade in goods and cultural and physical proximity are the key correlates for bilateral foreign equity holdings, e.g. all else equal, doubling physical distance reduces equity holdings by $61 \%$. This constitutes a puzzle since investors should shift their portfolios to remote countries, as those countries usually provide better diversification potential due to less synchronous business cycles. Instead, Lane and Milesi-Ferretti (2008) find that investors seem to forego this potential by holding equity in destinations with similar business cycles (as measured by the correlation coefficient of GDP growth rates). Portes and Rey (2005) also build on gravity models and find that they perform at least as well in explaining asset trade as goods trade. According to their study, the size of asset markets in host and source countries, next to informational symmetries, are the main determinants of gross transaction flows. They confirm the distance puzzle, but view distance as a proxy for informational asymmetries. Aviat and Coeurdacier (2007) directly address the study by Portes and Rey (2005) and find, not surprisingly, that the distance puzzle is drastically reduced once trade in goods is controlled for. They employ a simultaneous gravity equations 
framework and point out the complementarity of trade in goods and assets, e.g. all else equal, a $10 \%$ increase in bilateral goods trade raises bilateral asset holdings by $6 \%$ to $7 \%$. Bekaert and Wang (2009) confirm that proxies for capital market openness and familiarity and information variables are the dominant factors for explaining home bias. De Santis (2009) shows that portfolio re-allocation in the period 1997-2005 has generally gone in the theoretically predicted direction. That is, international investment flows move to reduce initial underweight and to exploit the highest marginal diversification benefits.

\section{Data and Definitions}

Our dataset comprises 23 OECD countries with annual data between 1980 and 2007. Data on GDP and private and public consumption are taken from the OECD Annual National Accounts database and are expressed in US-\$ at constant prices with base year 2000. To obtain per capita estimates, population data from the same source are used. Data for our portfolio equity wealth measure and the home bias measures are taken from various sources, including the International Monetary Fund's Coordinated Portfolio Investment Survey (CPIS) and International Financial Statistics (IFS), Datastream and the External Wealth of Nations Mark II (EWN II) dataset compiled by Lane and Milesi-Ferretti (2007). ${ }^{4}$

\subsection{Consumption and Output}

We concentrate on idiosyncratic real consumption and output shocks and thus define variables relative to a worldwide aggregate, which is computed here as the sum of consumption and output respectively across all countries in our sample (at constant prices and converted to US dollars at PPP exchange rates). Table 1 provides some summary statistics for home relative

\footnotetext{
${ }^{4}$ The CPIS data may be subject to measurement errors. However, no superior or even comparable data source exists to date.
} 
to world consumption and output growth for the period 1980-2007. The first three columns show mean growth rates of output, private (household) consumption and total (private plus public) consumption. The last three columns of table 1 show the correlation between domestic and world output growth and between domestic and world consumption growth, respectively. For most countries, the GDP correlation is substantially higher than the consumption correlation. Exceptions where the consumption correlation exceeds the output correlation are printed in bold. This is the case for Canada, Germany, Ireland (private consumption only), New Zealand, the UK, and the US (total consumption only). Only for New Zealand, Ireland and the UK is the difference substantial. Overall, it demonstrates the well-known consumption correlation puzzle (see Backus et al., 1992, Obstfeld, 1994, 1995 , and Lewis, 1999) and the lack of consumption risk sharing over the sample period.

[Table 1 about here.]

\subsection{Equity Home Bias}

We define overall portfolio equity wealth (PEW) as a percentage of GDP the following way:

$$
P E W_{i, t}=\frac{M C A P_{i, t}+F A_{i, t}-F L_{i, t}}{G D P_{i, t}}
$$

where $M C A P_{i, t}$ is the equity market capitalization of country $i, F A_{i, t}$ and $F L_{i, t}$ are country i's foreign asset and foreign liability equity holdings equity, respectively. Data for $\mathrm{MCAP}_{\mathrm{i}, \mathrm{t}}$ are retrieved from Datastream, and $\mathrm{FA}_{\mathrm{i}, \mathrm{t}}$ and $\mathrm{FL}_{i, t}$ are taken from the EWN II database and carefully updated with IFS data for recent years. The first two columns of Table 2 show the portfolio equity wealth measures for the years 1990 and 2005. Two characteristics stand out. The wealth measures, and therefore the potential for risk insurance, vary hugely across country, but are uniformly increasing over time. Countries like 
Mexico, Portugal and Greece with less mature and deep financial markets stand opposite to countries like Switzerland, the UK and Sweden with overall portfolio equity wealth positions exceeding GDP.

The past two decades not only experienced a pronounced increase in overall portfolio equity wealth, but also a concomitant decline in equity home bias, as witnessed by Bracke and Schmitz (2009) and Sørensen et al. (2007). Like these studies, we will use the equity home bias (EHB) measure proposed by Poterba (1991):

$$
E H B_{i, t}=1-\frac{\frac{F E A_{i, t}}{P E W_{i, t} * D P_{i, t}}}{1-\frac{M C A P_{i, t}}{M C A P_{w, t}}}
$$

where $M C A P_{w, t}$ is worldwide equity market capitalization. Important to note is that the EHB measure relies on our measure for overall portfolio equity wealth to ensure consistency in the empirical work. Under this definition, EHB takes on values between zero and one. A value of zero implies the absence of equity home bias; the share of domestic equity in the investment portfolio is consistent with the relative size of the domestic and world equity market. In contrast, a value of one implies that a country has exclusively invested at home.

Columns 3 and 4 of Table 2 show the absolute home bias measures for the years 1990 and 2005. It is apparent that financial globalization has changed the structure of portfolio equity wealth positions since its onset in the mid1980s. EHB is decreasing for all countries with the exception of Belgium and Mexico. Especially small open economies like Austria, Norway, and foremost, the Netherlands lead the ranks of the most financially integrated economies. Nonetheless, an average EHB of 0.56 in 2005 shows that investors' portfolio choices at the time were still tilted toward domestic equity and that market integration remained far from perfect. 
[Table 2 about here.]

\subsection{Foreign Investment Bias}

We now turn to the definition of foreign investment bias, where we need information on bilateral foreign asset holdings to assess the role of the geographical (national) composition of foreign equity portfolios. Until recently, no reliable data were available in this field, which is one of the main reasons that the geographical dimension of portfolio investment is under investigated so far (see De Santis, 2009). However, the CPIS does provide such information from 2011 onward. It is the first and unique survey of its kind that records foreign portfolio equity and debt investment holdings for around 70 source and 240 host countries in a comprehensive and consistent way. For our sample of 23 OECD countries, we are considering foreign portfolio equity holdings in 33 host countries over the period 2001-2007, capturing the large majority of all foreign equity investment. The remainder is invested in other - RoW - countries for which no additional information is available.

To determine a country's foreign investment bias, we need to define both optimal and actual portfolio weights of foreign equity, where we need to correct for the country' s home bias. Taking the international CAPM (Solnik, 1974) as our starting point, market equilibrium is obtained when all investors hold the world portfolio. In the absence of home bias, it implies that the optimal, benchmark portfolio weight of country k's equity in the global market portfolio should be $\mathrm{MCAP}_{\mathrm{k}, \mathrm{t}} / \mathrm{MCAP}_{\mathrm{w}, \mathrm{t}}$. Since we do not know the composition of portfolio investment across the RoW countries, we exclude them from our measurement of the optimal weight and define the optimal weight of country k's equity in the foreign portfolio of country $i$ as:

$$
w_{i, k, t}^{*}=\frac{M C A P_{k, t}}{M C A P_{w, t}-M C A P_{R o W, t}-M C A P_{i, t}}
$$


The actual weight of country i's equity in country k's foreign portfolio can be simply defined as the ratio of country i's holdings of country $k$ 's equity $F E_{i, k, t}$ and its total foreign equity holdings $\mathrm{TFE}_{\mathrm{i}, \mathrm{t}} .{ }^{5}$

$w_{i, k, t}^{a c t}=\frac{F E_{i, k, t}}{T F E_{i, t}}$

Using equations (3) and (4) we can now define the foreign investment bias that is underinvestment or overinvestment - of country $i$ in country k, where the definition is such that $a+$ implies underinvestment and a - implies overinvestment, in the following way - see also Holinksi (2010) and BW09:6,7

$$
F i b_{i, k}^{1}=w_{i, k}^{*}-w_{i, k}^{a c t}
$$

To arrive at a measure of the overall difference between a country's actual foreign equity portfolio and the ideal world portfolio, we aggregate the bilateral foreign investment bias measures across countries. in the following way:

$$
S F i b_{i}^{a b s}=\frac{1}{2} \sum_{k=1}^{N}\left|F i b_{i, k}\right|
$$

Where $\mathrm{N}$ is the number of host countries excluding the own country (32). $\mathrm{SFib}^{\text {abs }}$ is bounded between 0 and 1 . A zero value of the average foreign

\footnotetext{
${ }^{5}$ TFE is corrected for RoW portfolio holdings too to make the definition of actual weights consistent with that of the optimal portfolio weights. Note that total foreign portfolio equity, $\mathrm{FA}_{\mathrm{i}, \mathrm{t}}$, in (1) and (2) is measured independently from total foreign portfolio equity $\mathrm{TFE}_{\mathrm{i}, \mathrm{t}}$, in (4). The former comes from IFS and EWN II databases, while the latter uses data from the CPIS. As a result, small measurement errors arise. ${ }^{6}$ For ease of illustration, we drop the time subscript in the foreign investment bias formulas without loss of generality.

${ }^{7}$ BW09 also propose a normalized bilateral measure where overinvestment and underinvestment are normalized differently, resulting in asymmetric treatment of overinvestment and underinvestment. In our view, both this asymmetry and the problem of aggregating differently normalized bilateral overinvestment and underinvestment into one aggregate measure make the normalized measure less appropriate for our purpose. This notion was confirmed by some preliminary estimation results.
} 
investment bias measure SFib ${ }^{\text {abs }}$ implies that a country's foreign equity portfolio is an exact replication of the world equity portfolio, accounting for the country's degree of equity home bias. Higher values imply larger deviations from the world portfolio.

Since information on the geography of portfolio investment is only available for the years from 2001 onward, we focus on the cross-country dimension and work with time invariant measures of SFib in equation (6). They are obtained as averages over the period 2001-2007. Obviously, it imposes an additional constraint, but unreported evidence shows that cross-country variation in the SFib measure dominates time-variation. As a consequence, we feel a time-invariant treatment is warranted. ${ }^{8}$ The first column of Table 3 reports the average foreign investment bias value over the period 2001-2007 for each country.

[Table 3 about here]

Comparing tables 2 and 3 shows that low home bias and low foreign investment bias do not necessarily coincide. Japan for instance has high only Greece has higher - equity home bias as late as 2005, but a much better than average diversified foreign equity portfolio according to our foreign investment bias measure. It provides suggestive evidence that foreign investment bias deserves attention in its own right as an indicator of international risk sharing.

\subsection{Weighted Foreign Investment Bias}

The country-specific average foreign investment bias measure as defined in equation (6) provides an appropriate aggregate proxy for the degree to which a country's foreign equity portfolio deviates from the optimal world portfolio. However, the measure weighs individual underinvestment and

\footnotetext{
${ }^{8}$ The alternative of limiting the sample to $2001-2007$ is unattractive as the time dimension in the panel gets too short.
} 
overinvestment in foreign countries equally and, thus, neglects the fact that not all foreign countries provide equal diversification benefits.

To better appreciate this point, let's take the example of the Netherlands. The Netherlands is close to Germany, both in terms of distance - they share a long border -, in terms of a similar industrial structure and in terms of economic integration. These two countries are major trading partners and share a common currency. As a result, their business cycles are strongly correlated. Comparing the Netherlands to for instance Australia gives a completely different picture. The countries lie on opposite sides of the globe, have different industrial structures and relatively limited trade. In general one could argue that the distance between Australia and the Netherlands is large in all relevant aspects. From a portfolio perspective, it would suggest that overinvestment in Germany and underinvestment in Australia will provide less diversification benefits to the Netherlands than overinvestment in Australia and underinvestment in Germany. Obviously, we would like our country-specific foreign investment bias variables to reflect this dimension of diversification.

To this end, we develop two alternative foreign investment bias measures that explicitly take into account a country's foreign equity portfolio composition and the pattern of its overinvestment and underinvestment. The first one weights individual overinvestment and underinvestment with a normalized distance variable. Because now the sign matters, no absolute values of bilateral foreign investment biases are taken. The appropriate formula is:

$$
S F i b_{i}^{d i s t}=100 * \sum_{k=1}^{N}\left(\frac{d i s t_{i, k}}{\sum_{k=1}^{N} d i s t_{i, k}}\right) F i b_{i, k}
$$

Where dist $_{i, k}$ is the distance in miles between the capitals of countries $\mathrm{i}$ and $\mathrm{k}$. The factor 100 is included for reasons of comparability with the other 
measures. ${ }^{9}$ In general, high values of SFid ${ }^{\text {dist }}$ emerge for a given country $i$ when the country overinvests in other countries nearby and underinvests in countries far away. Then, in nearby countries the bilateral negative Fib carries a low weight, whereas in faraway countries the bilateral positive Fib carries a high weight. Assuming that nearby countries generally are closer in economic structure and performance and, thus, have less diversification potential than faraway countries, high values of SFib ${ }^{\text {dist }}$ correspond with low diversification and low consumption sharing. ${ }^{10}$

The second weighting scheme depends on bilateral real GDP correlations over the period $1980-2007$ as follows:

$$
\operatorname{SFib}_{i}^{\text {corr }}=\sum_{k=1}^{N}\left(\frac{\rho_{i, k}}{\sigma_{i}\left(\rho_{i, k}\right)}\right) F i b_{i, k}
$$

The bilateral foreign investment bias is weighted with the normalized bilateral correlation coefficient of real GDP growth between the countries concerned. Note that the correlation weights in equation (8) do not sum to one as the weights are normalized by the country specific cross-sectional standard deviation of bilateral correlation coefficients $\left(\sigma_{\mathrm{i}}\left(\rho_{\mathrm{i}, \mathrm{k}}\right)\right)$. We prefer this normalization over the simple sum of bilateral correlation coefficients because of the presence of negative correlations which for some countries can make the sum quite small, blowing up the multiplication factors for $\mathrm{Fib}_{\mathrm{i}, \mathrm{k}}{ }^{11}$

It can be easily shown from equation (8) that high values of SFib ${ }^{\text {corr }}$ correspond with high diversification and high consumption sharing. High

\footnotetext{
${ }^{9}$ Alternatively, we used logarithmic distances for the normalization in equation (8). The regression results are only marginally affected and remain unreported here. They are available upon request from the authors. ${ }^{10}$ Note that equation (7) can also be interpreted as a covariance between distance and overinvestment and underinvestment.

${ }^{11}$ As a robustness check, we also computed a correlation weighted foreign investment bias measure using the format of equation (7) with the sum of bilateral correlation coefficients serving as normalization factor. Then, the weights again sum to one. Regression results with this alternative measure turn out to be qualitatively similar to those obtained with the measure from equation (8).
} 
values of SFib ${ }^{\text {corr }}$ emerge for a given country when the country overinvests in countries whose economy is weakly correlated with the domestic economy and underinvests in countries whose economy is strongly correlated with the domestic economy. Then, countries with bilateral positive Fib (underinvestment) on average carry a high weight due to the high bilateral GDP correlation, whereas countries with bilateral negative Fib (overinvestment) on average carry a low weight due to the low bilateral GDP correlation.

Columns 2 and 3 of table 3 contain average values over the period 20012007 for SFib ${ }^{\text {dist }}$ and SFib ${ }^{\text {corr }}$. We note that the bilateral correlation coefficient between SFib ${ }^{\text {abs }}$ and SFib ${ }^{\text {dist }}$ is significantly positive $(0.86)$, while the bilateral correlation coefficient between SFib ${ }^{\text {abs }}$ and SFib ${ }^{\text {corr }}$ is significantly negative (0.74). It implies that countries whose foreign equity portfolio composition is far away from the optimal world portfolio - high SFib ${ }^{\text {abs }}$ - typically overinvest in countries close by - high SFib ${ }^{\text {dist }}$ - as well as typically overinvest in countries that are similar in terms of GDP movements - low SFib ${ }^{\text {corr }}$. It provides suggestive evidence that our overall foreign investment bias measure SFib ${ }^{\text {abs }}$ can be used as a proxy for portfolio composition effects. We now turn to the regression analysis to test whether foreign investment bias can be shown to significantly affect consumption risk sharing.

\section{Consumption risk-sharing}

Our estimation strategy proceeds in several steps. All estimations are carried out for two time horizons, the entire time period 1980-2007 and the more recent sub period 1990-2007. It is often argued that cross-border portfolio investment accelerated only in the 1990s such that assuming a stable relationship back to 1980 is not warranted. Estimation results for both periods provide further insights. Moreover, for our consumption measure we 
use either private consumption or the sum of private and public consumption as defined by the OECD Annual National Accounts database. Both consumption measures have been used in previous research. In addition, their joint use serves as a robustness check for our results and allows some inferences on the role of government in smoothing consumption. The panel data regressions have the following general form

$\Delta \log C_{i, t}-\Delta \log C_{t}=\alpha+\beta_{t}\left(\Delta \log G D P_{i, t}-\Delta \log G D P_{t}\right)+v_{i, t}$

where the disturbance term $v_{i, t}$ is specified as the one-way error component model with a country-specific effect and a stochastic error term. ${ }^{12}$ The $\beta$ coefficient measures the co-movement between idiosyncratic GDP and idiosyncratic consumption and is allowed to be time-variant. In the perfect risk-sharing case the coefficient is equal to zero such that domestic consumption growth is independent from domestic output shocks.

In our benchmark specification, we introduce interaction terms in equation (9). To this purpose, we model $\beta$ as a function of portfolio wealth (PEW) and equity home bias (EHB). Both measures enter in deviation from an (unweighted) average across countries and time. Here, a bar above the variable indicates an average.

$\beta_{t}=\beta_{0}+\beta_{1}\left(P E W_{i, t}-\overline{P E W}\right)+\beta_{2}\left(E H B_{i, t}-\overline{E H B}\right)$

A country with average overall portfolio equity wealth and equity home bias will experience consumption risk-sharing of degree $\left(1-\beta_{0}\right)$. Since PEW is a measure of a country's financial development and market completeness, we expect above average values of PEW to lead to higher risk sharing. This implies a negative $\beta_{1}$ coefficient. Higher than average equity home bias on

\footnotetext{
${ }^{12}$ As in Sørensen et al. (2007), all estimations are performed as weighted least squares to correct for the presence of cross-country heteroskedasticity in our sample.
} 
the other hand indicates low levels of foreign diversification and low consumption risk sharing, implying a positive value for $\beta_{2}$.

The joint inclusion of a volume-based wealth measure and a portfolio composition variable is novel. Past research employed either volume-based measures of different classes of foreign asset and liability holdings (Sørensen et al., 2007, Kose et al., 2007, Fratzscher and Imbs, 2009, Bracke and Schmitz, 2009) or decomposition measures like our absolute EHB measure (French and Poterba, 1991, Sørensen et al., 2007). We argue that only the joint inclusion in a consumption risk-sharing framework is able to single out the ceteris paribus contributions of the two measures.

Subsequently, we test our hypothesis that equity home bias is an insufficient measure of foreign portfolio composition as it only accounts for overall foreign equity, not for the degree of diversification within the foreign equity portfolio. For that reason we extend the specification of $\beta$ to include a country-specific foreign investment bias variable $\mathrm{SFib}^{j}$ (in deviation of its cross-country average), where $j$ is the index identifying each of our three aggregate foreign investment bias measures ( $\mathrm{j}$ equals abs, dist, or corr):

$$
\beta_{t}=\beta_{0}+\beta_{1}\left(P E W_{i, t}-\overline{P E W}\right)+\beta_{2}\left(E H B_{i, t}-\overline{E H B}\right)+\beta_{3}\left(S F i b_{i}^{j}-\overline{S F i b^{j}}\right)
$$

We expect above average foreign investment bias to reduce consumption risk sharing, implying a positive value for coefficient $\beta_{3}$ in case SFib ${ }^{\text {abs }}$ or SFib ${ }^{\text {dist }}$ are used, and a negative value when SFib ${ }^{\text {corr }}$ is used.

[Table 4 about here]

Table 4 presents results for private consumption for the periods 1990-2007 and 1980-2007, while table 5 contains similar results for total consumption. ${ }^{13}$ First, we discuss the private consumption regressions for the period 1990-

\footnotetext{
${ }^{13}$ Due to incomplete data, Ireland and Iceland were deleted from the regression analysis, leaving 21 countries in the sample.
} 
2007. In our view, the more recent period is the most important one to analyze as it fully takes into account the effects of global financial integration.

The results for the basic specification - equation (9) - confirm our hypothesis. All coefficients are significant and have the correct sign. The GDP coefficient of 0.80 suggests that consumption risk-sharing is far from perfect on average as for countries with average portfolio wealth and equity home bias only 20 percent of idiosyncratic risk is diversified.

The interaction coefficient on portfolio equity wealth is -0.25 in the basic regression for private consumption. It implies that countries with 10 percent points more equity wealth - in terms of their GDP - obtain 2.5 percent more consumption risk sharing. Lower equity home bias contributes to private consumption smoothing as well. The marginally significant and positive coefficient of 0.34 shows that a 10 percentage point below average equity home bias increases risk sharing with 3.4 percent.

We now turn to the role of foreign investment bias. The results in table 4 show that the coefficients on both SFib ${ }^{\text {abs }}$ and SFib ${ }^{\text {dist }}$ are significant and positive. It confirms our hypothesis that the composition of the foreign equity portfolio has an independent effect on consumption risk sharing, separate from the equity home bias effect. We fail to find a significant effect of the correlation weighted foreign investment bias measure SFib ${ }^{\text {corr }} .{ }^{14}$ An in-depth analysis of this puzzle is beyond the scope of this article and is left for future research. The results for 1980-2007 are qualitatively similar to those for 1990-2007. The most important difference is the lack of significance of the equity home bias variable for the longer period.

\footnotetext{
${ }^{14}$ This finding is consistent with BW09 who report that neither the bilateral stock market return correlation nor the industrial structure gap measure becomes significant with the correct sign in their analysis.
} 
We now turn to the results for total consumption in table 5. The results are roughly in line with those for private consumption. Portfolio wealth, equity home bias and foreign investment bias generally have the correct sign. Equity home bias is significant only for one specification now. The correlation weighted measure SFib ${ }^{\text {corr }}$ becomes marginally significant in the period 19902007. The GDP coefficient value is about stable across sub periods but lower for total consumption than for private consumption, possibly due to the fact that governments use fiscal policies to contribute to consumption smoothing.

Overall, we conclude that the results provide supportive evidence of the claim that foreign investment bias, when measured appropriately, plays a significant role in international consumption risk sharing. Put differently, our evidence shows that it is not only important to build a large foreign equity portfolio and reduce equity home bias. It is also the composition of this foreign equity portfolio that influences the degree to which foreign equity indeed is able to hedge idiosyncratic consumption risk.

To further illustrate the contribution of the various explanatory variables to consumption smoothing, we take the regression equation for private consumption over the period 1990-2007 with the highest explanatory power, which includes the distance-weighted foreign investment bias measure. We compute the overall amount of consumption risk smoothing per country as well as the individual contributions of each interaction term, evaluated for the average values over the period 2001-2007. Table 6 presents the results. The GDP column is the estimated value of $\left(1-\beta_{0}\right)$ from equation (11) and implies that $22 \%$ of idiosyncratic output risk was diversified away across countries over the period 2001-2007. The next three columns give the percentage contribution of each of the interaction terms, based on the estimated coefficients $\beta_{1}, \beta_{2}$, and $\beta_{3}$.

[Table 6 about here] 
A number of points stand out. First, the degree of consumption risk sharing varies between $69.6 \%$ (Switzerland) to $5.5 \%$ (Mexico). Second, in terms of overall consumption risk sharing, the eurozone countries - apart from the Netherlands - show below average performance and as a group rank from 13 to 20. It appears due to above average foreign investment bias and suggests eurozone countries invest too much in other - nearby and similar - eurozone countries. This increases their vulnerability to shocks within the eurozone. The Anglosaxon countries as well as the Scandinavian countries clearly outperform the continental European countries, Switzerland and the Netherlands excluded. Third, the table shows that there is quite some cross country heterogeneity in the sources of consumption risk sharing. For instance, Japan benefits from below average foreign investment bias as its foreign equity portfolio is much better diversified than that of most other countries $(+14.0 \%)$ but simultaneously has above average equity home bias $(-7.6 \%)$. Finland shows the opposite picture with below average equity home bias $(+8.4 \%)$ and above average foreign investment bias. Fourth, foreign investment bias alone can contribute as much as $15.2 \%$ to consumption risk sharing (Australia) as well as reduce consumption risk sharing by a similar percentage (Belgium, $-15.4 \%$ ). It strongly suggests that foreign investment bias is an important factor in consumption risk sharing.

\section{Conclusion}

In this paper, we contribute to the international consumption risk sharing literature by accounting for the role of foreign equity portfolio composition in international consumption risk sharing. First, we argue that it is not the size of foreign portfolio investment as a fraction of domestic wealth alone that provides risk sharing. In addition, the composition of the foreign asset portfolio should matter as well. The closer a country's foreign equity portfolio - conditional on the market value of that portfolio - approximates the world portfolio, the better its consumption risk sharing should be. The main goal of 
this paper is to develop three so-called foreign investment bias measures and empirically estimate their impact on consumption risk sharing.

The first foreign investment bias measure for each country aggregates the absolute difference between optimal and actual foreign equity portfolio weights. This measure just looks at deviations from the world portfolio, without accounting for the specific investment pattern a country chooses. Subsequently, we develop foreign investment bias measures that do take into account portfolio composition, using either distance weights or GDP correlation weights.

Our empirical analysis covers a group of 23 OECD countries during the financial globalization period 1980-2007. We use a panel regression framework to regress idiosyncratic consumption growth on idiosyncratic output growth where we specify the regression coefficient to be a function of a country's overall portfolio equity wealth, a country's equity home bias and a country's foreign investment bias. The results convincingly show that both the unweighted and the distance weighted foreign investment bias measure play a significant role in consumption risk sharing, complementing the effects of equity home bias and portfolio wealth. The correlation weighted measure fails to yield positive results. An in-depth analysis of this puzzle is left for future research. 


\section{References}

Ahearne, A. G., W. L. Griever and F. E. Warnock, 2004. Information costs and home bias: an analysis of U.S. holdings of foreign equities. Journal of International Economics, 62, 313-336.

Artis, M., Hoffmann, M., 2008. Financial Globalization, International Business Cycles, and Consumption Risk Sharing. Scandinavian Journal of Economics 110 (3), 447-471.

Asdrubali, P., Sørensen, B., and Yosha, O., 1996. Channels of Interstate Risk Sharing: United States: 1963-1990. The Quarterly Journal of Economics 111, 1081-1110.

Aviat, A., Coeurdacier, N., 2007. The Geography of Trade in Goods and Asset Holdings. Journal of International Economics 71, 22-51.

Backus, D., Kehoe, P., and Kydland, F., 1992. International Real Business Cycles. The Journal of Political Economy 100, 745-775.

Becker, S., Hoffmann, M., 2006. Intra- and International Risk-Sharing in the Short Run and the Long Run. European Economic Review 50, 777-806.

Bekaert, G., Wang, X., 2009. Home bias revisited. Columbia Business School Working Paper.

Bracke, T., Schmitz, M., 2011. Channels of International Risk-Sharing: Capital Gains versus Income Flows. International Economics and Economic Policy 8, 45-78.

Chan, K., V. Covrig and L. Ng, 2005. What determines the domestic bias and foreign bias? Evidence from mutual fund equity allocations worldwide. The Journal of Finance, 60, 1495-1534.

Cochrane, J., 1991. A Simple Test of Consumption Insurance. The Journal of Political Economy 99, 957-976.

De Santis, R., 2010. The Geography of International Portfolio Flows, International CAPM and the Role of Monetary Policy Frameworks. International Journal of Central Banking.

Fazio G., MacDonald R., and Melitz J., 2008. Trade Costs, Trade Balances and Current Accounts: An Application of Gravity to Multilateral Trade, Open Economies Review,

Fratzscher, M., Imbs, J., 2009. Risk Sharing, Finance and Institutions in International Portfolios. Journal of Financial Economics 94, 428-447.

French, K., Poterba, J., 1991. Investor Diversification and International Equity Markets. American Economic Review 81, 222-226.

Holinski, N., 2010. The Wealth of Nations: Global Imbalances and Adjustments in a Financially Integrated World. PhD Thesis, University Maastricht, the Netherlands. 
Kollmann, R., 1995. Consumption, Real Exchange Rates and the Structure of International Asset Markets. Journal of International Money and Finance 14, 191-211.

Kose, M., Prasad, E., and Terrones, M., 2009. Does Financial Globalization Promote Risk Sharing? Journal of Development Economics 89, 258270.

Lane, P., Milesi-Ferretti, G.M., 2001. The External Wealth of Nations: Measures of Foreign Assets and Liabilities for Industrial and Developing Nations. Journal of International Economics 55, 263-294.

Lane, P., Milesi-Ferretti, G., 2007. The External Wealth of Nations Mark II: Revised and Extended Estimates of Foreign Assets and Liabilities, 1970-2004. Journal of International Economics 73, 223-250.

Lane, P., Milesi-Ferretti, G.M., 2008. International Investment Patterns. The Review of Economics and Statistics 90 (03), 538-549.

LeRoy, S., Werner, J., 2001. Principles of Financial Economics. Cambridge University Press.

Lewis, K., 1996. What can Explain the Apparent Lack of International Consumption Risk-Sharing?. The Journal of Political Economy 99, 267287.

Lewis, K., 1999. Trying to Explain Home Bias in Equities and Consumption. Journal of Economic Literature XXXVII, 571-608.

Mace, B., 1991. Full Insurance in the Presence of Aggregate Uncertainty. The Journal of Political Economy 99, 928-956.

Melitz, J., 2007. North, South and distance in the gravity model, European Economic Review 51 (2007) 971-991.

Melitz, J., Zumer, F., 1999. Interregional and International Risk Sharing and Lessons for EMU. Carnegie-Rochester Conference Series on Public Policy 51, 149-188.

Obstfeld, M., 1994. Are Industrial-Country Consumption Risks Globally Diversified?, in Leiderman, L., Razin, A. (Eds.), Capital Mobility: The Impact of Consumption, Investment and Growth. Cambridge University Press.

Obstfeld, M., 1995. International Capital Mobility in the 1990s, in Kenen, P.B. (Ed.), Understanding Interdependence. Princeton University Press.

Obstfeld, M., 2001. The Six Major Puzzles in International Macroeconomics Solved. NBER Macroeconomics Annual 2000 15, 339-390.

Obstfeld, M., Rogoff, K., 1996. Foundations of International Macroeconomics. MIT Press, Cambridge.

Portes, R., Rey, H., 2005. The Determinants of Cross-Border Equity Flows. Journal of International Economics 65, 269-296. 
Shiller, R., 1993. Macro Markets: Creating Institutions for Managing Society's Largest Economic Risks. Oxford University Press.

Solnik, B., 1974. An Equilibrium Model of the International Capital Markets. Journal of Economic Theory 8, 500-524.

Sørensen, B., Wu, Y.-T., Yosha, O. and Zhu, Y., 2007. Home Bias and International Risk Sharing: Twin Puzzles Separated at Birth. Journal of International Money and Finance 26, 587-605.

Sørensen, B., Yosha, O., 1998. International Risk Sharing and European Monetary Unification. Journal of International Economics 45, 211-238.

Stockmann, A., Tesar, L., 1995. Tastes and Technology in a Two-Country Model of the Business Cycle: Explaining International Comovements. American Economic Review 85, 168-185. 
Table 1 Consumption and Output Growth (1980-2007)

\begin{tabular}{|c|c|c|c|c|c|c|}
\hline \multirow[t]{2}{*}{ Country } & \multicolumn{3}{|c|}{ Mean growth (\%) } & \multicolumn{3}{|c|}{ Correlation with World } \\
\hline & GDP & $C^{h}$ & $C^{t}$ & GDP & $C^{h}$ & $C^{t}$ \\
\hline Australia & 1.89 & 1.92 & 1.94 & 0.46 & 0.16 & 0.19 \\
\hline Austria & 1.86 & 1.70 & 1.65 & 0.33 & 0.19 & 0.19 \\
\hline Belgium & 1.78 & 1.43 & 1.34 & 0.53 & 0.39 & 0.29 \\
\hline Canada & 1.72 & 1.56 & 1.39 & 0.70 & 0.75 & 0.72 \\
\hline Denmark & 1.88 & 1.48 & 1.44 & 0.31 & 0.24 & 0.15 \\
\hline Finland & 2.30 & 2.25 & 2.02 & 0.61 & 0.51 & 0.51 \\
\hline France & 1.53 & 1.55 & 1.56 & 0.54 & 0.48 & 0.47 \\
\hline Germany & 0.79 & 0.56 & 0.46 & 0.70 & 0.74 & 0.71 \\
\hline Greece & 1.57 & 1.95 & 1.81 & 0.32 & 0.25 & 0.28 \\
\hline Iceland & 2.06 & 2.53 & 2.54 & 0.20 & 0.09 & 0.12 \\
\hline Ireland & 4.22 & 2.71 & 2.68 & 0.38 & 0.52 & 0.32 \\
\hline Italy & 1.55 & 1.72 & 1.63 & 0.53 & 0.19 & 0.26 \\
\hline Japan & 1.99 & 1.82 & 1.99 & 0.41 & 0.24 & 0.19 \\
\hline Mexico & 1.00 & 1.27 & 1.16 & 0.13 & 0.00 & -0.06 \\
\hline Netherlands & 1.79 & 1.11 & 1.36 & 0.67 & 0.46 & 0.42 \\
\hline New Zealand & 1.35 & 1.66 & 1.56 & 0.23 & 0.49 & 0.47 \\
\hline Norway & 2.42 & 2.28 & 2.28 & 0.23 & 0.16 & 0.04 \\
\hline Portugal & 2.20 & 2.29 & 2.50 & 0.24 & 0.15 & 0.12 \\
\hline Spain & 2.28 & 2.07 & 2.38 & 0.52 & 0.47 & 0.40 \\
\hline Sweden & 1.85 & 1.20 & 1.08 & 0.64 & 0.55 & 0.52 \\
\hline Switzerland & 0.86 & 0.74 & 0.78 & 0.83 & 0.40 & 0.44 \\
\hline United Kingdom & 2.02 & 2.47 & 2.15 & 0.61 & 0.80 & 0.79 \\
\hline United States & 1.91 & 2.15 & 1.92 & 0.86 & 0.86 & 0.87 \\
\hline World & 1.75 & 1.85 & 1.73 & 1.00 & 1.00 & 1.00 \\
\hline
\end{tabular}

Notes: GDP refers to output, $\mathrm{C}^{\mathrm{h}}$ to private (household) consumption and $\mathrm{C}^{\mathrm{t}}$ to total (private plus public) consumption. 
Table 2 Portfolio Wealth and Equity Home Bias

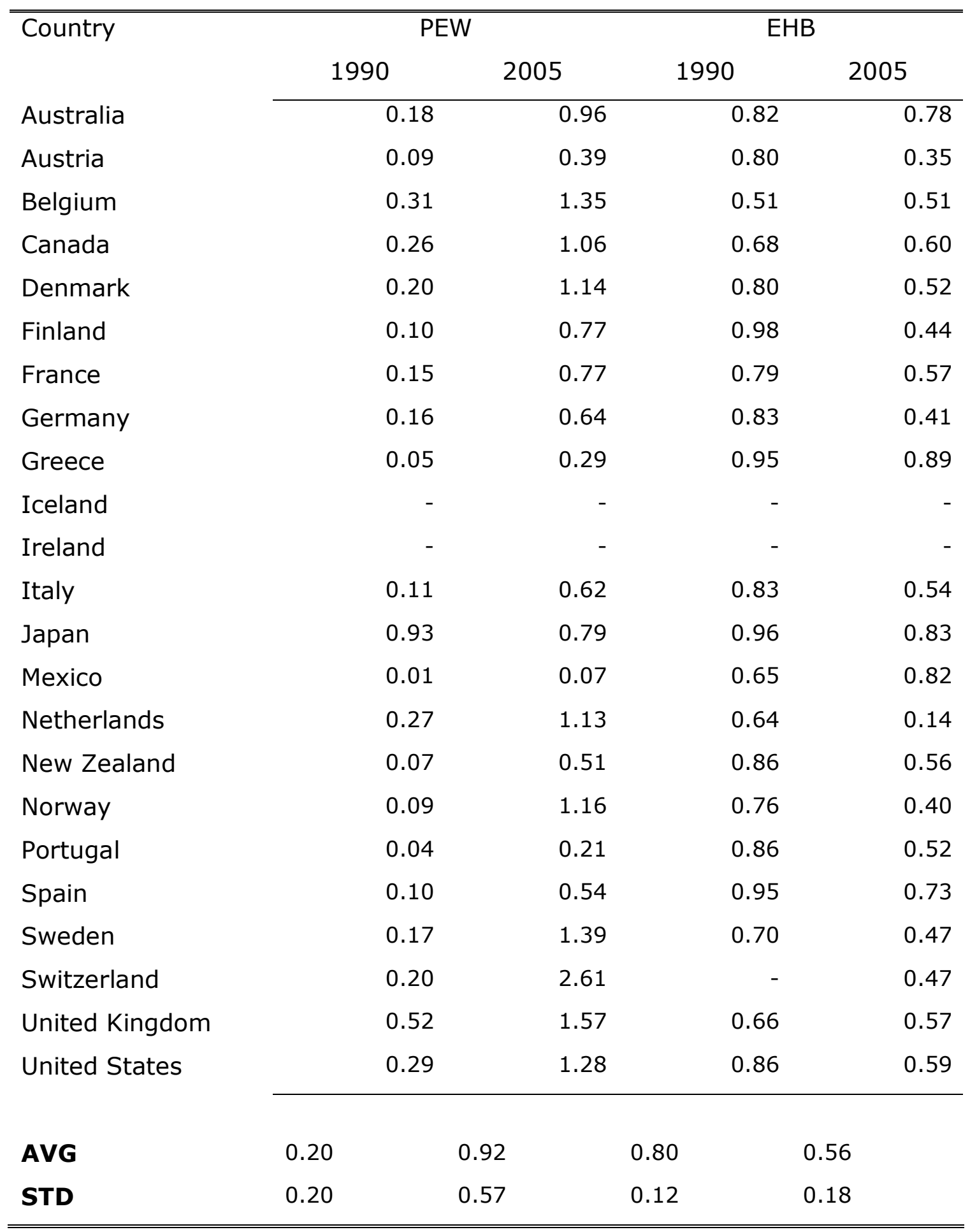


Table 3 Foreign Investment Bias

(avg. 2001-2007)

\begin{tabular}{|c|c|c|c|}
\hline \multicolumn{4}{|l|}{ Country } \\
\hline & SFib ${ }^{\text {abs }}$ & SFib ${ }^{\text {dist }}$ & SFib ${ }^{\text {corr }}$ \\
\hline Australia & 0.21 & -0.07 & -0.27 \\
\hline Austria & 0.40 & 1.57 & -0.77 \\
\hline Belgium & 0.51 & 2.01 & -0.88 \\
\hline Canada & 0.14 & 0.37 & -0.30 \\
\hline Denmark & 0.26 & 0.90 & -0.18 \\
\hline Finland & 0.46 & 1.63 & -0.44 \\
\hline France & 0.45 & 1.63 & -0.52 \\
\hline Germany & 0.42 & 1.60 & -0.41 \\
\hline Greece & 0.31 & 0.75 & -0.25 \\
\hline Iceland & 0.38 & 0.83 & -0.30 \\
\hline Ireland & 0.24 & 0.74 & -0.10 \\
\hline Italy & 0.40 & 1.36 & -0.09 \\
\hline Japan & 0.10 & 0.01 & 0.09 \\
\hline Mexico & 0.56 & 1.11 & -0.54 \\
\hline Netherlands & 0.16 & 0.53 & -0.16 \\
\hline New Zealand & 0.28 & 0.64 & -0.56 \\
\hline Norway & 0.23 & 0.75 & 0.13 \\
\hline Portugal & 0.56 & 1.64 & -0.67 \\
\hline Spain & 0.53 & 1.57 & -0.72 \\
\hline Sweden & 0.22 & 0.80 & -0.22 \\
\hline Switzerland & 0.28 & 1.10 & -0.12 \\
\hline United Kingdom & 0.25 & 0.43 & 0.17 \\
\hline United States & 0.17 & 0.24 & -0.23 \\
\hline AVG & 0.33 & 0.96 & -0.32 \\
\hline STD & 0.14 & 0.22 & 0.02 \\
\hline
\end{tabular}


Table 4 Regression results private consumption risk sharing

\begin{tabular}{|c|c|c|c|c|c|c|}
\hline & & Int & raction & $\mathrm{ms}$ & & \\
\hline & GDP & PEW & EHB & FIB & Obs & Adj. $R^{2}$ \\
\hline $1990-20$ & & & & & & \\
\hline & $0.80 * * *$ & $-0.25 * * *$ & $0.34 *$ & & 372 & 0.735 \\
\hline & $(0.03)$ & $(0.06)$ & $(0.20)$ & & & \\
\hline SFib ${ }^{a b s}$ & $0.79 * * *$ & $-0.16 * *$ & $0.33 *$ & $0.66 * * *$ & 372 & 0.741 \\
\hline & $(0.03)$ & $(0.07)$ & $(0.20)$ & $(0.24)$ & & \\
\hline SFib dist & $0.78 * * *$ & $-0.16 * *$ & $0.47 * *$ & $0.15 * * *$ & 372 & 0.744 \\
\hline & $(0.03)$ & $(0.07)$ & $(0.21)$ & $(0.05)$ & & \\
\hline SFib ${ }^{\text {corr }}$ & $0.80 * * *$ & $-0.22 * * *$ & $0.35 * *$ & -0.13 & 372 & 0.735 \\
\hline & $(0.03)$ & $(0.07)$ & $(0.20)$ & $(0.14)$ & & \\
\hline $1980-20$ & & & & & & \\
\hline & $0.79 * * *$ & $-0.23 * * *$ & 0.10 & & 521 & 0.681 \\
\hline & $(0.03)$ & $(0.06)$ & $(0.17)$ & & & \\
\hline SFib ${ }^{\text {abs }}$ & $0.79 * * *$ & $-0.18^{* * *}$ & 0.16 & $0.44 * *$ & 521 & 0.687 \\
\hline & $(0.03)$ & $(0.06)$ & $(0.17)$ & $(0.20)$ & & \\
\hline SFib ${ }^{\text {dist }}$ & $0.78 * * *$ & $-0.17 * *$ & 0.25 & $0.12 * *$ & 521 & 0.689 \\
\hline & $(0.03)$ & $(0.06)$ & $(0.18)$ & $(0.05)$ & & \\
\hline SFib ${ }^{\text {corr }}$ & $0.79 * * *$ & $-0.24 * * *$ & 0.08 & 0.03 & 521 & 0.678 \\
\hline & $(0.03)$ & $(0.07)$ & $(0.18)$ & $(0.12)$ & & \\
\hline
\end{tabular}

Notes: The dependent variable is idiosyncratic private consumption growth. The independent variables are idiosyncratic GDP growth (GDP) augmented with interaction terms for portfolio wealth (PEW), equity home bias (EHB) and different measures of foreign investment bias (FIB). The regression intercept is suppressed. We use weighted least squares. Standard errors are in parentheses, where $* * *, * *$, and $*$ denote significance at the 1,5 and 10 percent level, respectively. 
Table 5 Regression results total consumption risk sharing

\begin{tabular}{|c|c|c|c|c|c|c|}
\hline & \multirow[b]{2}{*}{ GDP } & \multicolumn{3}{|c|}{ Interaction Terms } & \multirow[b]{2}{*}{ Obs } & \multirow[b]{2}{*}{ Adj. $R^{2}$} \\
\hline & & PEW & EHB & FIB & & \\
\hline \multicolumn{7}{|l|}{$1990-2007$} \\
\hline & $0.69 * * *$ & $-0.25 * * *$ & 0.20 & & 372 & 0.680 \\
\hline & $(0.03)$ & $(0.07)$ & $(0.19)$ & & & \\
\hline \multirow[t]{2}{*}{ SFib ${ }^{\text {abs }}$} & $0.68^{* * *}$ & $-0.13^{*}$ & 0.18 & $0.89 * * *$ & 372 & 0.698 \\
\hline & $(0.03)$ & $(0.07)$ & $(0.18)$ & $(0.22)$ & & \\
\hline \multirow[t]{2}{*}{ SFib ${ }^{\text {dist }}$} & $0.68 * * *$ & $-0.14 * *$ & $0.38 * *$ & $0.20 * * *$ & 372 & 0.704 \\
\hline & $(0.03)$ & $(0.07)$ & $(0.19)$ & $(0.05)$ & & \\
\hline \multirow[t]{2}{*}{ SFib ${ }^{\text {corr }}$} & $0.69 * * *$ & $-0.20 * *$ & 0.21 & $-0.19 *$ & 372 & 0.683 \\
\hline & $(0.03)$ & $(0.07)$ & $(0.19)$ & $(0.11)$ & & \\
\hline \multicolumn{7}{|l|}{$1980-2007$} \\
\hline & $0.66 * * *$ & $-0.21 * * *$ & 0.02 & & 521 & 0.637 \\
\hline & $(0.03)$ & $(0.06)$ & $(0.16)$ & & & \\
\hline \multirow[t]{2}{*}{ SFib $^{\text {abs }}$} & $0.68^{* * *}$ & $-0.14 * *$ & 0.12 & $0.65 * * *$ & 521 & 0.648 \\
\hline & $(0.03)$ & $(0.06)$ & $(0.16)$ & $(0.19)$ & & \\
\hline \multirow[t]{2}{*}{ SFib $^{\text {dist }}$} & $0.67 * * *$ & $-0.14 * *$ & 0.25 & $0.17^{* * *}$ & 521 & 0.653 \\
\hline & $(0.03)$ & $(0.06)$ & $(0.17)$ & $(0.05)$ & & \\
\hline \multirow[t]{2}{*}{ SFib ${ }^{\text {corr }}$} & $0.67 * * *$ & $-0.20 * * *$ & 0.04 & -0.06 & 521 & 0.637 \\
\hline & $(0.03)$ & $(0.06)$ & $(0.16)$ & $(0.10)$ & & \\
\hline
\end{tabular}

Notes: The dependent variable is idiosyncratic total consumption growth. The independent variables are idiosyncratic GDP growth (GDP) augmented with interaction terms for portfolio wealth (PEW), equity home bias (EHB) and different measures of foreign investment bias (FIB). The regression intercept is suppressed. We use weighted least squares. Standard errors are in parentheses, where $* * *, * *$, and $*$ denote significance at the 1,5 and 10 percent level, respectively. 
Table 6 Consumption Risk Sharing (\%)

\begin{tabular}{|c|c|c|c|c|c|c|}
\hline \multirow[t]{2}{*}{ Country } & \multicolumn{4}{|c|}{ Contribution of } & \multirow[b]{2}{*}{ Total } & \multirow[b]{2}{*}{ Rank } \\
\hline & GDP & PEW & $\mathrm{EHB}$ & FIB & & \\
\hline Australia & 22.0 & 7.4 & -3.5 & 15.2 & 41.0 & 8 \\
\hline Austria & 22.0 & -1.4 & 18.3 & -8.9 & 30.0 & 13 \\
\hline Belgium & 22.0 & 10.2 & 10.2 & -15.4 & 27.1 & 14 \\
\hline Canada & 22.0 & 9.5 & 4.5 & 8.6 & 44.6 & 7 \\
\hline Denmark & 22.0 & 9.3 & 8.3 & 0.9 & 40.5 & 9 \\
\hline Finland & 22.0 & 5.5 & 8.4 & -9.8 & 26.1 & 16 \\
\hline France & 22.0 & 6.0 & 0.2 & -9.8 & 18.4 & 17 \\
\hline Germany & 22.0 & 2.5 & 11.2 & -9.4 & 26.3 & 15 \\
\hline Greece & 22.0 & -2.5 & -9.4 & 3.2 & 13.2 & 18 \\
\hline \multicolumn{7}{|l|}{ Iceland } \\
\hline \multicolumn{7}{|l|}{ Ireland } \\
\hline Italy & 22.0 & 2.2 & 6.5 & -5.8 & 25.0 & 16 \\
\hline Japan & 22.0 & 6.8 & -7.6 & 14.0 & 35.2 & 10 \\
\hline Mexico & 22.0 & -6.0 & -8.4 & -2.2 & 5.5 & 21 \\
\hline Netherlands & 22.0 & 11.6 & 19.9 & 6.3 & 59.9 & 2 \\
\hline New Zealand & 22.0 & -0.9 & 7.0 & 4.7 & 32.8 & 12 \\
\hline Norway & 22.0 & 8.2 & 12.3 & 3.2 & 45.7 & 6 \\
\hline Portugal & 22.0 & -3.2 & 4.2 & -10.0 & 13.0 & 19 \\
\hline Spain & 22.0 & -0.7 & -1.0 & -8.9 & 11.4 & 20 \\
\hline Sweden & 22.0 & 14.5 & 9.3 & 2.4 & 48.3 & 5 \\
\hline Switzerland & 22.0 & 38.3 & 11.3 & -2.0 & 69.6 & 1 \\
\hline United Kingdom & 22.0 & 17.1 & 4.3 & 7.8 & 51.2 & 3 \\
\hline United States & 22.0 & 13.4 & 2.5 & 10.6 & 48.5 & 4 \\
\hline
\end{tabular}

